NBER WORKING PAPER SERIES

\title{
SUDDEN STOPS: DETERMINANTS AND OUTPUT EFFECTS IN THE FIRST ERA OF GLOBALIZATION, 1880-1913
}

\author{
Michael D. Bordo \\ Alberto F. Cavallo \\ Christopher M. Meissner \\ Working Paper 13489 \\ http://www.nber.org/papers/w13489
}

\author{
NATIONAL BUREAU OF ECONOMIC RESEARCH \\ 1050 Massachusetts Avenue \\ Cambridge, MA 02138 \\ October 2007
}

Comments from Claudia Goldin and seminar participants at Harvard have improved this paper. The standard disclaimer is applicable. Research support from the UK's ESRC under grant RES 156-25-0014 is warmly recognized. Corresponding author: Christopher M. Meissner, Department of Economics, University of California, Davis, CA 95616 cmmeissner@ucdavis.edu. The views expressed herein are those of the author(s) and do not necessarily reflect the views of the National Bureau of Economic Research.

(C) 2007 by Michael D. Bordo, Alberto F. Cavallo, and Christopher M. Meissner. All rights reserved. Short sections of text, not to exceed two paragraphs, may be quoted without explicit permission provided that full credit, including (C) notice, is given to the source. 
Sudden Stops: Determinants and Output Effects in the First Era of Globalization, 1880-1913 Michael D. Bordo, Alberto F. Cavallo, and Christopher M. Meissner

NBER Working Paper No. 13489

October 2007

JEL No. F21,F32,N1,N10

\begin{abstract}
$\underline{\text { ABSTRACT }}$
Using a sample of 20 emerging countries from 1880 to 1913 , we study the determinants and output effects of sudden stops in capital inflows during an era of intensified globalization. We find that higher levels of original sin (hard currency debt to total debt) and large current account deficits associated with reliance on foreign capital greatly increased the likelihood of experiencing a sudden stop. Trade openness and stronger commitment to the gold standard had the opposite effect. These results are robust for many sudden stop definitions used in the literature. Finally, we use a treatment effects model to show that after controlling for endogeneity sudden stops have a strong negative association with growth in per capita output. We also show that banking, currency and debt crises that were preceded by a sudden stop have much greater negative relation with growth than in the absence of a sudden stop.

Michael D. Bordo

Department of Economics

Rutgers University

New Jersey hall

75 Hamilton street

New Brunswick, NJ 08901

and NBER

bordo@econ.rutgers.edu

Alberto F. Cavallo

Department of Economics

Harvard University

Littauer Center

1805 Cambridge Street

Cambridge, MA 02138

acavallo@fas.harvard.edu

Christopher M. Meissner

Department of Economics

University of California, Davis

One Shields Avenue

Davis, CA 95616

and NBER

chris.meissner@econ.cam.ac.uk
\end{abstract}




\section{Introduction}

The pattern of sudden stops in capital inflows to emerging market countries in the last 30 years has great resonance to events which occurred the first era of globalization between 1880 and 1913. This is especially so when we examine events in the late $1880 \mathrm{~s}$ and early 1890s. In those years many emerging countries were beset by a drastic decline in capital flows from the core countries of Western Europe and many of these emerging markets suffered currency, banking and debt crises. These sudden stops of capital inflows have been at the root of volatile economic performance in many emerging markets both today and in this previous period.

Although capital flows declined in virtually every country in this period, the impact on the real economy and the incidence of crises differed markedly. These differences reflected similar factors to those stressed today: structural differences, exposure to shocks, institutions and policies. Especially important in that era was how much of a country's external and internal debt was denominated and made payable in a fixed amount of gold or other international currencies. This state has been called "original sin," and it is not a new problem. ${ }^{1}$ Like today, it exposed countries to the risk of balance sheet induced financial stress and possibly crises, a phenomenon resonant to the role of liability dollarization in the financial crises of the 1990s. Whether liability dollarization rendered countries more financially fragile or not was related to the presence of strong institutions and sound policy--what Caballero, Cowen and Kearns (2004) refer to as country and currency trust. Country trust is based on sound institutions, strong rule of law and stable political systems. Currency trust is based on the ability to adhere to a credible nominal anchor like the gold standard in the nineteenth century, which required following stable monetary policy and fiscal balance. ${ }^{2}$

This paper applies the methods of the recent empirical literature on sudden stops to the late $19^{\text {th }}$ and early $20^{\text {th }}$ century experience. We provide results that are directly comparable -and strikingly similar- to those of the more recent period which have

\footnotetext{
${ }^{1}$ See Eichengreen and Hausmann (1999) for an analysis of original sin in the contemporary period.

${ }^{2}$ See Bordo and Kydland (1996) for more on the effects of adherence to the Gold standard.
} 
analyzed sudden stops and financial crises. ${ }^{3} \mathrm{We}$ study a number of determinants of sudden stops, including the size of the trade deficit, the degree of trade openness in the economy, the levels of both hard currency debt and total debt, the currency composition of debt (original sin) and policy variables like the growth rate of money and reserve ratios.

Our results show that original sin, defined as the level of hard currency debt to total debt, is a very robust predictor of sudden stops. This provides evidence for the importance of balance sheet effects, with countries that owe large portions of their debt in gold or foreign currency facing serious difficulties in repaying their debt under the exchange rate depreciations that follow sudden stops.

Trade deficits in countries receiving capital inflows are also strongly associated with sudden stops. This illustrates that reliance on foreign capital may have made countries more financially fragile. We go on to show that this may have reduced their growth prospects because crises come along with lower growth rates of output. ${ }^{4}$

We find that trade openness reduces the probability of sudden stops, suggesting that the benefits of being able to quickly adjust to the current account imbalances are more important than the threat of opening up to external shocks. Similarly, higher gold coverage ratios (i.e., gold reserves / money in circulation) also reduce the probability of sudden stops, a fact that reflects the importance of signaling and currency trust in the ability to prevent crises.

Next, we look into the relationship between sudden stops and growth. There is no question that sudden stop events have historically been coupled with drops in output. But are sudden stops directly responsible for a substantial drop in output, or are these drops the result of other unobservable factors that also trigger the sudden stop itself? While most theoretical models of sudden stops establish a direct link between the sudden stop, balance sheet effects and drops in output, other authors like Chari et. al. (2005) present models where the sudden stop itself is beneficial for growth because it brings about an immediate positive increase in net exports. In this context then, the sudden stop becomes a turning point after which output starts to improve.

\footnotetext{
${ }^{3}$ See, for example, Calvo et al. (2004)

${ }^{4}$ Bordo and Meissner (2007) analyze capital inflows directly and find similar results.
} 
To answer these questions, we empirically control for the endogeneity of sudden stops using a treatment effects model. We conclude that sudden stops are still related to reductions in output growth even after accounting for endogeneity. The impact appears economically significant with drops in the growth rate averaging more than four percentage points below the long-run average growth rates. Additionally, we also find the impact on growth is larger when sudden stops are accompanied by financial crises. Banking, currency or debt crises that were preceded by sudden stops had an even greater negative impact on output growth than having a sudden stop alone.

This paper is organized as follows: Section 2 characterizes and identifies sudden stop events for our sample, performs a regression analysis on the determinants of the probability of sudden stops and studies robustness using several definitions commonly found in the literature. Section 3 considers the output effects of sudden stops and other financial crises by using a treatments effects model to control for endogeneity. Section 4 concludes.

\section{Characterizing Sudden Stops}

A sudden stop is characterized by a sharp cut-off of capital flows into a country. It reflects an abrupt unwillingness of foreigners to continue financing the country's current account deficit. It is often triggered by an event such as an increase in interest rates in the lending countries which reduces capital outflows or a sudden change in expectations regarding debt default in the borrowing country. As soon as the sudden stop takes place, the debtor finds it impossible any longer to finance its current account deficit. Foreign reserves can be used for a while to delay the adjustment, but eventually the current account deficit must be turned into a surplus with a sharp improvement in the trade balance and a compression of domestic absorption.

If the country is under a fixed exchange rate regime, like the gold standard which prevailed during our period of study, the adjustment must be made via a reduction in spending. In the face of sticky wages and prices this leads to an economic recession. Alternatively, the government may decide to devalue (alter its gold parity) or leave the gold standard, accelerating the real depreciation process. In theory, this could prevent a recession altogether, but as the experience of sudden stops in many emerging countries in 
the 1990s and early 2000s has shown, currency depreciations can lead to strong balance sheet effects, bankruptcies, financial crises and drops in output.

\subsection{Identifying Sudden Stops}

In this section we identify sudden stop events in our sample of 20 emerging market countries using several identification criteria that are common in the literature.

A sudden stop is generally defined as a large and unexpected fall in a country's net capital inflows, usually coupled with drops in economic activity. In theory, sudden stops can occur without a current account reversal if foreign reserves are used to maintain the level of the current account deficit. In practice however, reserves are seldom large enough to be a practical or permanent solution, and eventually the current account needs to adjust. This makes identification of sudden stops easier, given that current account (or trade balance) data can be used, and is particularly convenient for our period of study, for which direct capital flows data is scarce.

Using simple balance of payment accounting identities, we first construct a proxy for net capital inflows by subtracting the trade balance from changes in foreign reserves. ${ }^{5}$

Next, we create several indicator variables for sudden stops. Our main indicator, which we call "SS1", follows Calvo et al. (2004) closely and considers a country as having a sudden stop during a given year if there is an annual drop in net capital inflows of at least two standard deviations below the mean of the year-to-year changes for the period, and/or it is the first year of a drop in net capital inflows that exceeds 3 percent of nominal GDP over a period shorter than four years, and there is a drop in real GDP (of any magnitude) during that year or the following year. ${ }^{6}$

With this definition, we are requiring reversals to be sudden and large relative to the volatility experienced by that particular country during the period. This is important, since countries could differ substantially in the type and stability of foreign capital

\footnotetext{
${ }^{5}$ Balance of Payments $=$ Current Account + Net Capital Inflows (NKI) - Change in Reserves, where Current Account $=$ Trade Balance + Net Factor Payment + Unilateral Transfers. Therefore NKI $=$ Change in Reserves - CA.

By using trade balance data, our NKI proxy includes net factor payments and unilateral transfers which, although potentially important in magnitude for some countries in this period, are not expected to change significantly on a yearly-basis.

${ }^{6}$ The specific conditions, such as the two standard deviation cutoff, are common in the literature. See Calvo et al (2004) and Catão (2006).
} 
inflows and investments. Our identification strategy also allows for reversals which may take longer to materialize but still represent a significant share of GDP. Finally, the inclusion of the drop in output allows us to differentiate sudden stops crises from positive terms of trade shocks which also lead to current account reversals but are coupled with increases in GDP and real exchange rate appreciations.

We applied these criteria to a sample of 20 emerging market countries between 1880 and 1913: Argentina, Australia, Austria, Belgium, Brazil, Canada, Chile, Denmark, Finland, Greece, India, Italy, Japan, New Zealand, Norway, Portugal, Russia, Spain, Sweden and the United States. ${ }^{7}$ The data was compiled from previous work by Bordo et. al. (2001), Bordo and Meissner (2006), Flandreau and Zúmer (2004), Mitchell (1992) and Obstfeld and Taylor (2003), among others. See the Appendix for further details.

The sudden stop events identified in the data are shown in Table 1. During the period 1880-1913, there were 34 sudden stops in the countries considered; 17 countries (85\% of total) were affected and 9 countries ( $45 \%$ of total) had two or more sudden stops. ${ }^{8}$

Figure 1 shows the pattern of average net capital inflows to GDP and the global number of sudden stops in each year. Capital inflows increased considerably in the early 1880 s and then experienced a sharp drop in the 1890s. Sudden stops occurred every time there was a downturn in capital inflows, but there is evidence of "bunching" around the early 1890's and around 1900. These are well-known periods of macroeconomic instability in capital importing countries, as analyzed extensively in the literature on financial crises in the late nineteenth century. ${ }^{9}$

Sudden stops were by far the most common type of financial disruption during this period. Figure 2 compares the frequency of sudden stops with that of other financial crises: banking, currency and debt crises. We define frequency as the number of years a country was in crisis divided by the total possible years of observation (excluding years of ongoing crises). As can be seen, the probability of a sudden stop was the highest of all events in the pre 1914 period at 5.3\%. Crises were rarer events than sudden stops, with

\footnotetext{
${ }^{7}$ Following Bordo and Eichengreen we treat the US as an emerging country although in most respects it was an advanced country with the principal exception that it was a net recipient of capital inflows until the turn of the twentieth century and it had a relatively unstable banking system.

${ }^{8}$ See Table A2 in the Appendix for further details.

${ }^{9}$ See Bordo et al (2001), Bordo and Eichengreen (2002).
} 
banking crises being the most likely at 3.5\%, followed by currency crises at $3.1 \%$ and debt crises at $1 \% .^{10}$

In terms of timing, sudden stops tended to occur shortly before other financial crises. About $40 \%$ of sudden stop events were followed by a financial crisis (either debt, currency or banking crisis) within only three years. ${ }^{11}$ This provides some evidence for the link between sudden stops, balance sheet effects and financial crises. In section 3 we study in more detail the interaction between sudden stops and other financial crises through their combined effects on output.

Figure 3 shows discount rates for core countries (UK, Germany and France), which were the main sources of funds for emerging economies. The years that are shaded are those with one or more sudden stops. One of the most striking features is that during the two most prominent periods of sudden stops, around 1890 and 1900, interest rates in the core lending countries were raised sharply. The rise in discount rates in the years preceding 1890, for example, reflected a reaction by the Bank of England and other central banks to a decline in their gold reserves reflecting burgeoning capital outflows to Latin America and other emerging regions to finance an investment boom. The boom occurred in a period of depressed economic conditions in England and the other European countries when low interest rates and sluggish investment made the higher rates of return in the Americas and Australasia very attractive. The boom ended as the European economy recovered at the end of the decade and investment opportunities reappeared. In the face of rising aggregate demand the Bank of England raised its discount rate from $2 \frac{1}{2}$ to $4 \%$. This was matched by the German Reichsbank and other central banks. This policy shock precipitated a massive slowdown in investment abroad. ${ }^{12}$

Overall, this period experienced a pattern of events that included external shocks coming from a tightening of monetary policy in the core, a rise in sovereign yield spreads, a drying up of capital flows, current account reversals, a decline in nominal exchange rates in countries with paper currencies, a decline in real output and a spate of

\footnotetext{
${ }^{10}$ Bordo and Meissner ( 2007) using a larger sample of 30 countries find a fairly similar pattern for the three traditional types of crises. The probability of a banking crisis was $3.8 \%$, of a currency crisis $2.2 \%$ and of a debt crisis $1 \%$.

${ }^{11}$ See Table A3 and Figure A2 in the Appendix for a country-by-country analysis.

${ }^{12}$ See Bordo (2006)
} 
financial crises. See Bordo (2006) for more descriptive statistics on capital flows, exchange rates, spreads and financial crises during this period.

\subsection{The Determinants of Sudden Stops}

Many factors can contribute to both the likelihood of sudden stops and their effect on economic activity. The degree of openness can play an important but ambiguous role. It can make a country more vulnerable to sudden stops simply because it may be more exposed to foreign shocks. But it can also make a country less vulnerable because it can facilitate the current account adjustment needed once a sudden stop occurs. ${ }^{13}$ For example Calvo and Talvi (2005) demonstrate how a depreciating real exchange rate requires a greater compression by the non-traded goods sector in the case of a relatively closed economy.

The extent of original sin can also seriously impact the balance sheet of firms and especially the banking sector. Exchange rate depreciation increases the local currency value of liabilities relative to local currency assets. This can contribute to a banking crisis as the collateral backing bank loans deteriorates. It can also lead to a debt crisis for governments whose debts are in hard currency and whose tax revenues are in local currency. Both a banking crisis and the expectation of a debt crisis can generate currency crises, as international reserves which serve to back the banking system's liabilities as well as the government's balance sheet are threatened (Dooley 2000, Mishkin 2003).

More generally, sound fiscal and monetary policies and strong institutions can help to both prevent and stabilize the effects of sudden stops.

\subsection{Regression Analysis of Determinants}

In order to study the determinants of sudden stops, we run a pooled probit regression with heteroscedasticity robust, standard errors clustered at the country level. Our data set is an unbalanced panel and our observational unit is the country-year.

Our dependent variable is the indicator variable for sudden stops, SS1. We use as independent variables several factors identified in the literature as important

\footnotetext{
${ }^{13}$ See, for example, Milesi-Ferreti and Razin (1998). For more on openness and sudden stops, see Cavallo and Frankel (2004).
} 
determinants: the ratio of the trade balance to GDP, the degree of openness (exports plus imports divided by GDP), the degree of "original sin" (share of total public debt denominated in gold or foreign currency), the gold coverage ratio (reserves / money in circulation), the ratio of gold or foreign currency debt to GDP, the ratio of total debt to GDP and the growth rate of the money stock. ${ }^{14}$ We also control for real GDP per capita and lag all variables one period. ${ }^{15}$ To control for time effects, we include the English consol rate in all regressions.

\subsection{Estimation results}

Our results are summarized in Table 2 where coefficients shown are average marginal effects on the probability of a sudden stop. Model (1) is our main specification with key explanatory variables. Most results are strong and statistically significant.

As expected, the coefficient on trade balance to GDP is negative and statistically significant. Sudden stops affect countries with negative trade balance to GDP ratios. The higher this ratio, the lower the country's dependence on foreign capital and therefore the lower the likelihood of a sudden stop. Our estimates show that an increase of 4.7 percentage points in the trade balance to GDP ratio, which represents a one standard deviation change for this variable in our sample, decreases the probability of a sudden stop (conditional on keeping other variables at their means) by $0.02 .{ }^{16}$ Given that the conditional probability of a sudden stop is only 0.02 when we evaluate all variables at their means, this represents a $100 \%$ decrease in the predicted probability. The trade balance to GDP is clearly a strong -though perhaps unsurprising- determinant of sudden stops.

We also find that higher levels of trade openness can greatly decrease the probability of experiencing a sudden stop. An increase of 17.9 percentage points in trade openness,

\footnotetext{
${ }^{14}$ These variables have also been used in similar papers for more modern historical periods. See Calvo et al (2004), Cavallo and Frankel (2006), Sturzenegger and Guidotti (2005) and Edwards (2004). Many of our results in this section are directly comparable to those in these studies.

${ }^{15}$ Many papers in the literature use lagged variables to control for endogeneity, but it is not really a solution given the high persistency in the series. We include lags to follow the literature, but show in Appendix Table A5 that our results are robust to the removal of all lags. Other authors control for endogeneity using instrumental variable techniques. For example, Cavallo and Frankel (2004) use gravity estimates to control for endogeneity in the degree of trade openness. However, most of these studies find that results do not vary significantly after controlling for endogeneity.

${ }^{16} 0.047 *(-0.424)=0.02$
} 
also a one standard deviation change in our sample, decreases the predicted conditional probability by 0.018 or $90 \%$. This supports the view that openness makes the adjustment process easier (improving the trade balance is simpler if the economy is already heavily engaged in international trade), and is in line with empirical results by Edwards (2004), Cavallo and Frankel (2004) and Calvo et al. (2004) for the more recent historical period.

Among policy variables, the gold coverage ratio has a significant negative effect on the probability of a sudden stop. A one standard deviation increase, equal to 31 percentage points in our sample, decreases this probability by 0.019 , or $95 \%$. This variable, measured by the ratio of gold reserves to money in circulation, is taken here as a proxy for the degree of commitment to a sound monetary policy and adherence to the gold standard. ${ }^{17}$ Our results then support the view that among emerging countries a high gold coverage ratio signals the country's commitment to stable exchange rates, raises currency trust and reduces the chances of a sudden stop.

Among the debt variables, the currency composition of debt is very important, as shown by the positive and significant coefficients on original sin. This provides evidence for the importance of balance sheet effects in our empirical model. The higher the debt denominated in hard currency or gold, the higher the contractionary balance sheet effects, and therefore the higher the chances of facing a sudden stop. ${ }^{18}$ A one standard deviation increase of 33 percentage points increases the probability of Sudden Stops by 0.02 or $100 \%$.

It is important to note that our analysis does not focus on the reasons for the high degrees of original sin in many of these countries. As Eichengreen and Hausmann (2003) point out, creditors can be reluctant to lend in local currency because a country has weak institutions and is prone to manipulating the value of its currency. But original sin can also be a result of other factors and market imperfections beyond a country's control. ${ }^{19}$ Nations with good reputations or solid fundamentals can be obliged to issue debt in hard

\footnotetext{
${ }^{17}$ See Figures A3 and A4 in the Appendix

${ }^{18}$ A related variable is the level of currency mismatch, which measures the degree by which hard currency liabilities are offset with hard currency assets. A measure used by Bordo and Meissner (2007) is calculated as (hard currency debt - reserves / exports). As pointed out by Goldstein and Turner (2004) and Bordo and Meissner (2006), a country with higher currency mismatch could find it difficult to repay hard currency debt in the event of a depreciation. We have included this variable in some model specifications (not shown), but results are not significant for our sample in this period.

${ }^{19}$ See for example Bordo, Meissner and Redish (2004) and Flandreau and Sussman (2004) for discussions on the determinants and pace of graduation from original sin.
} 
currency, and oppositely, reputedly poor risk countries like Russia in the late nineteenth century and Brazil today have managed to sell a large amount of local currency debt to international markets. Regardless of its particular causes then countries suffering from it may be more prone to liquidity runs and balance sheet effects. Our results show that original sin had a large influence on the probability of experiencing a sudden stop during the 1880-1913 period possibly because of its impact on balance sheets and expectations about balance sheets.

In contrast to the compositional effects of debt (original sin), Table 2 shows that the level of hard currency liabilities to GDP does not have a significant impact on probabilities. This suggests that how much a country owed was not necessarily a problem; what really mattered was what percentage of that debt was denominated in hard currency. In model (2) we test for the level of total debt to GDP and find similar results.

The coefficients for the level of real GDP per capita and the growth of money supply have the expected signs, but are not statistically significant and model (3) shows that our main results are robust to the removal of these control variables. Finally, although standard in the literature, the inclusion of the trade balance to GDP variable is potentially problematic for identification, given its importance in our definitions of sudden stops. Nevertheless, model (4) shows that our results -particularly for original sin- are not affected by the removal of this variable.

Table 3 summarizes the effects of a one standard deviation change in each of the main independent variables. Notably, all of these variables have similar impact on the predicted probability of a sudden stop when we consider their actual volatility in our sample. Given that the predicted conditional probability of a sudden stop when we evaluate all variables at their means is only two percent per year across our sample, the economic significance of these regression coefficients is very strong. 


\subsection{Robustness}

We now construct two alternative sudden stop indicator variables to show that our main results are robust to the various definitions of sudden stops found in the literature.

Our second sudden stop variable, labeled SS2, does not condition on output drops at all. In essence this is a broader definition that focuses exclusively on large net capital inflow reversals, regardless of the initial impact on output.

The third sudden stop dummy, labeled SS3, requires a drop in the real output growth rate. It is possible, given lags in the economy, that growth continues for a while even in the presence of a sudden stop. An example would be an infrastructure investment that takes some time to affect output, like a railroad which facilitates settlement of a remote region. In theory though, when a sudden stop takes place there should be at least a slowdown in the output growth rate, and that is what SS3 captures. This is also a broader definition than SS1.

Applying these criteria to our sample, we find 63 sudden stop crises under both SS2 and SS3, although the countries and dates differ between them (see Table A2 in the Appendix for details). A close comparison between the three indicator variables shows that when there is a large and sudden reversal in net capital inflows (as measured by SS2) there may not be an immediate effect on output, but soon the growth rate slows (as measured by SS3) and in most cases output ends up falling within two years (as measured by SS1).

We repeat the regression analysis using our main specification (model 1 in Table 2) for these alternative sudden stop measures and show the results in Table 4.

Under SS2 and SS3, trade openness changes sign but losses significance, while the level of hard currency debt to GDP becomes a relevant predictor. However, most of our results, including the trade balance to GDP, original sin and gold coverage ratios, remain similar to SS1 in both magnitude and significance. 


\section{Sudden Stops, Financial Crises and Growth}

In this section we study the effects of sudden stops on the dynamics of output growth. We place special interest in the way sudden stops interact with other financial crises (currency, debt and banking crises) that may follow.

Estimating a growth regression using a sudden stop dummy may be problematic due to a potential endogeneity problem. Most sudden stop identification criteria involve some sort of conditioning on output drops. Even if they do not, sudden stops are still inherently endogenous because unobserved factors that contribute to economic downturns may also be working to create sudden stops. Moreover, there may be reverse causality: sudden stops affect output, but output affects sudden stops as well.

The estimation of a continuous variable like output per capita using a potentially endogenous binary variable can be attempted using a treatment effects regression. In addition to controlling for the endogeneity of the sudden stop dummy, this model also allows us to estimate the double impact of variables like trade openness on output, both directly via its marginal effect in the growth equation and indirectly through the impact on the probability of sudden stops.

In these growth regressions we use the broadest definition for sudden stop, SS2, as the dependent variable. Given that this definition includes events where output does not drop immediately, our estimation results provide a lower bound for the negative effects on output of sudden stops. ${ }^{20}$ Furthermore, our robustness analysis in the previous section shows that our results on determinants are robust to the choice of the sudden stop indicator. ${ }^{21}$

\footnotetext{
${ }^{20}$ Moreover, we show in Appendix Table A4 that the results in this section are robust to the use of the narrowest sudden stop definition, SS1.

${ }^{21}$ We choose to use SS1 (which conditions on output drops) in the determinants analysis simply because it is the standard definition used in the literature.
} 


\subsection{Regression Analysis of Output Growth}

Since our main interest is to analyze the effect of a possibly endogenous binary variable (sudden stop dummy) on growth, we use the endogenous treatment effects model. ${ }^{22}$ Our empirical specification starts with a growth equation:

$$
\text { (1) } g_{i, t}=\alpha+\beta X_{i, t}+\delta D_{i, t}^{s s}+\mu_{i}+\varepsilon_{i t}
$$

where $g_{i, t}$ is real GDP per capita growth for country $\mathrm{i}$ at time $\mathrm{t} ; X_{i, t}$ is a vector of independent variables; $D_{i, t}^{s s}$ is a sudden stop dummy; $\mu_{i}$ are unobserved time-invariant and country-specific effects; while $\alpha$ is a constant and $\varepsilon_{i, t}$ is the idiosyncratic error term.

Our sudden stop dummy $D_{i, t}^{s s}$ is an endogenous binary variable that depends on the realization of an unobserved latent variable $L_{i, t}^{*}$ according to:

$$
\begin{aligned}
& \text { (2) } D_{i, t}^{s s}= \begin{cases}1 & \text { if } L_{i, t}^{*}>0 \\
0 & \text { otherwise }\end{cases} \\
& \text { (3) } L_{i, t}^{*}=a W_{i(.)}+\xi_{i, t}
\end{aligned}
$$

where $W_{i(.)}$ is a set of control variables and $\xi_{i, t}$ is a random error term. ${ }^{23}$ Under assumptions of normality, equations (2) and (3) can be written as a probit model. The treatment effects model simply allows for correlation between the error term in the probit model and the growth regression. ${ }^{24}$

\footnotetext{
${ }^{22}$ Ranciere, Tornell and Westermann (2006) use this procedure to analyze the impact of financial liberalization on the probability of crises and growth. Edwards (2004) and Edwards (2005) use a related three-step mechanism to study the effects of sudden stops and current account reversals on growth. Similarly, Razin and Rubinstein (2004) study the growth effects of exchange rate regimes and currency crises. All of these papers focus on the recent crisis experience of the late $20^{\text {th }}$ and early $21^{\text {st }}$ centuries.

${ }^{23}$ The subscript (.) means there may be different lags for different variables.

${ }^{24}$ Formally, the model requires the following assumptions:
}

i) $(\varepsilon, \xi) \square N(0, Z)$ where $\mathrm{Z}=\left(\begin{array}{cc}\sigma_{\varepsilon}^{2} & \pi \\ \pi & 1\end{array}\right)$ and ii) $(\varepsilon, \xi)$ independent of $\mathrm{X}$ and $\mathrm{W}$. 
To illustrate what our model is actually doing consider the simple two-step procedure for estimation. First, the treatment equation for the probability of a sudden stop is estimated using a probit regression of sudden stops on a set of independent controls $W_{i(.)}$ and a hazard is then obtained for each observation. ${ }^{25}$ Second, the growth equation (1) is estimated including this hazard as an additional independent variable. This model is a generalization of Heckman's bivariate selection model to the treatment effects context and can be also estimated in one step by maximum likelihood. ${ }^{26}$ This is the procedure we follow.

In the treatment regression, $W_{i(.)}$ includes the same variables as our main probit in section 2 (model 2 in Table 4), with the exception of real per capita income. Most of these variables are strong determinants of sudden stops, but are expected not to affect output growth directly.

In the growth regression, $X_{i, t}$ includes variables that are standard in the growth literature: log of initial real GDP per capita, inflation, government spending to GDP ratio, trade openness, education enrolment, population growth and the investment to GDP ratio.

Note that the level of trade openness is included in both the growth and treatment regressions. This is not a problem. In fact, this model is identified even when all variables are included in both equations (i.e. when $W_{i, t}=X_{i, t}$ ) due to the non-linearity of the probit treatment equation. ${ }^{27}$ Our exclusion restriction is that all of the variables in the probit model besides openness do not belong in the growth model. ${ }^{28}$

\footnotetext{
${ }^{25}$ The hazard, also called the "Inverse Mills ratio" is defined by: $h_{i}=\left\{\begin{array}{cc}\phi\left(\hat{a} W_{i, t}\right) / \Phi\left(\hat{a} W_{i, t}\right) & \text { if } \mathrm{D}_{\mathrm{i}, \mathrm{t}}^{s s}=1 \\ -\phi\left(\hat{a} W_{i, t}\right) /\left[1-\Phi\left(\hat{a} W_{i, t}\right)\right] & \text { if } \mathrm{D}_{\mathrm{i}, \mathrm{t}}^{s s}=0\end{array}\right\}$ where $\Phi$ and $\phi$ are the c.d.f and density functions of the normal distribution.

${ }^{26}$ The Heckman model was initially developed in the wage equation context to deal with selection based on unobservables (for example, when only wages for employed people are observed) and later generalized. The difference between the wage equation and the treatment context is that in the latter the outcome is observed for all units, whether "treated" or not (i.e. we observe growth both with or without a sudden stop). ${ }^{27}$ The model is identified even if $W_{i, t}=X_{i, t}$ due to the non-linearity of the probit treatment equation, but Monte Carlo simulations have shown that in finite samples this leads to weak identification. The reason is a high degree of collinearity between the hazard and the regressors in the outcome equation. "Exclusionary restrictions", variables in the treatment equation that are not in the outcome equation, provide stronger identification.

${ }^{28}$ See Maddala (1983) and Woolridge (2002) for more detailed specification requirements.
} 


\subsection{Estimation Results}

Estimation results under maximum likelihood are shown in Table 5. The bottom panel shows results for the treatment equation while the top panel shows results for the growth equation. It is important to note that the number of observations drops significantly as a consequence of jointly estimating both output and treatment equations. ${ }^{29}$ This is the reason why the treatment equation results are not identical to those of the probit regression in section 2. We focus attention on the top panel in Table 5, which shows the results from the growth equation.

Model (A) is our basic growth regression with the endogenous sudden stop dummy variable included. Sudden stops are shown to have a strong negative effect on real GDP. Our point estimate suggests that growth is four percentage points lower when a sudden stop occurs. The coefficient is statistically significant across all model specifications. This provides a lower bound to the direct impact of sudden stops on output, given that we are using our broadest indicator variable, SS2, which essentially captures sharp net capital inflow reversals without requiring immediate drops in GDP.

As expected, we find that inflation has a strong negative impact on growth. A one percent increase in the inflation rate reduces the growth rate by 0.18 percentage points. The investment to GDP ratio has a positive impact of even greater magnitude. A one percent increase in investment to GDP leads to a 0.25 percent increase in the growth rate. Population growth has a negative effect and its coefficient is close to one.

Another important result is the indirect effect of sudden stops on growth through the interaction with financial crises. As mentioned before, 40 percent of our sudden stop events were followed by either a currency, banking or debt crisis within three years. The specification in model (B) includes a dummy variable for financial crises, which takes a value of one if there is any kind of financial crisis during that year and zero otherwise. The coefficient is positive but not significantly different from zero. However, model (C) replaces this dummy with an indicator of a financial crisis that occurs shortly after a sudden stop (within 3 years). These are financial crises which are very likely linked to the previous sudden stop. In this case, the negative output effect of financial crises is more

\footnotetext{
${ }^{29}$ The countries included are Argentina, Australia, Canada, Denmark, Italy, Norway, Spain and the US.
} 
than doubled and the coefficient becomes statistically significant. Financial crises which come shortly after a sudden stop lead on average to an additional 3.6 percentage point drop in the growth rate.

Finally, as emphasized by Ranciere, Tornell and Westermann (2006), the treatment effects model allows us to differentiate direct and indirect effects on growth for those variables that are included both in the growth and treatment equations. Our results show that trade openness has both a positive direct effect on growth and a positive indirect effect by reducing the probability of sudden stops. We can calculate the total effect of trade openness by using the estimated coefficients. For a given increase, we first compute the marginal effect on the probability of a sudden stop using the probit coefficients, then we multiply this by the estimated coefficient of sudden stops in the growth regression and finally we add the direct effects of openness on growth. Using the estimates of model (A) in Table 5, we find that an increase of 10 percentage points in trade openness increases the growth rate by 1.1 percentage points. The direct effect on growth is 0.9 percentage points while the indirect effect -via a reduction in the probability of sudden stops- is 0.2 percentage points.

\section{Conclusions}

Our analysis of the determinants and output effects of sudden stops in emerging economies, between 1870 and 1913, shows that the pattern of events was remarkably similar to the experience of the 1990 s and first years of the $21^{\text {st }}$ century. Financial globalization a century ago made many countries quite vulnerable to external shocks via capital inflows as today.

Among determinants, we find that low levels of original sin, high levels of trade openness and sound monetary policies are important to reduce the probability of experiencing a sudden stop. Other authors have shown similar results for the more recent period. $^{30}$

Balance sheet effects, a result of the combination of high levels of original sin and currency depreciation, may play an important role not only as a determinant of sudden

\footnotetext{
${ }^{30}$ See Calvo, Izquierdo and Mejia (2004), Cavallo and Frankel (2006), among others.
} 
stops but also in explaining why financial crises that are triggered by sudden stops are far worse in terms of their effect on GDP than those which are unrelated to them.

Overall, the lessons from the long run appear to be that sound debt management and the development of a large trade sector will allow emerging countries to escape financial turmoil. But indeed, what emerging countries really need to do to protect themselves from repeated episodes of sudden stops and crises is to mature and develop the sound financial institutions of an advanced economy. Today's emergers may wish to investigate the historical experience of countries that were the emergers of a century ago (like the US, Canada, Australia, New Zealand and the Scandinavian countries), to find out how they learned from the experiences of their financial crises and were able to advance to greater financial stability. ${ }^{31}$ As Caballero, Cowan and Kearns (2004) put it, many countries have yet to develop country and currency trust. The determinants of these deeper fundamentals remains an open question but one that needs investigation as global capital markets become increasingly connected.

\footnotetext{
${ }^{31}$ On learning from crises, see Bordo (2007) and Rosenthal and Hoffman (2007).
} 


\section{References}

Aghion, P., P. Bacchetta and A. Banerjee (2000). "A simple model of monetary policy and currency crises." European Economic Review 44(4-6): 728-738.

Bordo, M., B. Eichengreen, D. Klingebiel and M. S. Martinez-Peria (2001). "Is the crisis problem growing more severe?" Economic Policy 16(32): 51.

Bordo, M. D. (1992). Financial crises. Aldershot, Hants, England ; Brookfield, Vt., USA, E. Elgar Pub.

Bordo, M. D. (2006). "Sudden Stops, Financial Crises, and Original Sin in Emerging Countries: Déjà vu?" National Bureau of Economic Research Working Paper Series No. 12393.

Bordo, M. D. (2007). "Growing Up to Financial Stability." National Bureau of Economic Research Working Paper Series No. 12993.

Bordo, M. D. and B. Eichengreen (2002). "Crises Now and Then: What Lessons from the Last Era of Financial Globalization." National Bureau of Economic Research Working Paper Series No. 8716.

Bordo, M. D. and C. M. Meissner (2006). "The role of foreign currency debt in financial crises: 1880-1913 versus 1972-1997." Journal of Banking \& Finance 30(12): 3299-3329.

Bordo, M. D. and C. M. Meissner (2007). Financial Crises, 1880-1913: The Role of Foreign Currency Debt The decline of Latin American economies : growth, institutions, and crises. S. Edwards, G. Esquivel and G. Márquez. Chicago, University of Chicago Press.

Bordo, M. D., C. M. Meissner and A. Redish (2005). How 'Original Sin' was overcome: the evolution of external debt denominated in domestic currencies in the United States and the British Dominions 1800-2000. Other people's money : debt denomination and financial instability in emerging market economies. B. J. Eichengreen and R. Hausmann. Chicago, University of Chicago Press: vii, 296.

Bordo, M. D. and H. Rockoff (1996). "The Gold Standard as a `Good Housekeeping Seal of Approval'." National Bureau of Economic Research Working Paper Series No. 5340.

Caballero, R. J., K. Cowan and J. Kearns (2005). "Fear of Sudden Stops: Lessons From Australia and Chile." Journal of Policy Reform 8(4): 313-354.

Calvo, G. A., A. Izquierdo and L.-F. Mejia (2004). "On the Empirics of Sudden Stops: The Relevance of Balance-Sheet Effects." National Bureau of Economic Research Working Paper Series No. 10520.

Calvo, G. A., A. Izquierdo and E. Talvi (2006). "Phoenix Miracles in Emerging Markets: Recovering without Credit from Systemic Financial Crises." National Bureau of Economic Research Working Paper Series No. 12101.

Calvo, G. A. and E. Talvi (2005). "Sudden Stop, Financial Factors and Economic Collpase in Latin America: Learning from Argentina and Chile." National Bureau of Economic Research Working Paper Series No. 11153.

Catão, L. (2005). "Sudden Stops and Currency Drops: A Historical Look." IMF Working Papers $(06 / 133)$.

Cavallo, E. A. and J. A. Frankel (2004). "Does Openness to Trade Make Countries More Vulnerable to Sudden Stops, Or Less? Using Gravity to Establish Causality." National Bureau of Economic Research Working Paper Series No. 10957. 
Cespedes, L. F., R. Chang and A. Velasco (2004). "Balance Sheets and Exchange Rate Policy." American Economic Review 94(4): 1183-1193.

Chari, V. V., P. Kehoe and E. R. McGrattan (2005). "Sudden Stops and Output Drops." National Bureau of Economic Research Working Paper Series No. 11133.

Dooley, M. P. (2000). "A model of crises in emerging markets." Economic Journal 110(460): 256.

Edwards, S. (2004). "Thirty Years of Current Account Imbalances, Current Account Reversals, and Sudden Stops." IMF Staff Papers 51: 1.

Edwards, S. (2005). "Capital Controls, Sudden Stops and Current Account Reversals." National Bureau of Economic Research Working Paper Series No. 11170.

Eichengreen, B. and M. Adalet (2005). "Current Account Reversals: Always a Problem?" National Bureau of Economic Research Working Paper Series No. 11634.

Eichengreen, B. and R. Hausmann (1999). "Exchange Rates and Financial Fragility." National Bureau of Economic Research Working Paper Series No. 7418.

Eichengreen, B., R. Hausmann and U. Panizza (2003). "Currency Mismatches, Debt Intolerance and Original Sin: Why They Are Not the Same and Why it Matters." National Bureau of Economic Research Working Paper Series No. 10036.

Flandreau, M. and N. Sussman (2005). Old Sins. Other people's money : debt denomination and financial instability in emerging market economies. B. J. Eichengreen and R. Hausmann. Chicago, University of Chicago Press: vii, 296.

Flandreau, M., F. Zumer and Organisation for Economic Co-operation and Development. Development Centre. (2004). The making of global finance 1880-1913. Paris, Development Centre of the Organisation for Economic Co-operation and Development.

Goldstein, M. and P. Turner (2004). Controlling currency mismatches in emerging markets. Washington, DC, Institute for International Economics.

Guidotti, P. E., F. Sturzenegger and A. n. Villar (2004). "On the Consequences of Sudden Stops." Economia 4(2): 171-214.

Hoffman, P. T., G. Postel-Vinay and J.-L. Rosenthal (2007). Surviving large losses : financial crises, the middle class, and the development of capital markets. Cambridge, Mass., Belknap Press of Harvard University Press.

Kindleberger, C. P. (1996). Manias, panics, and crashes : a history of financial crises. New York, Wiley.

Kostelenos, G. C. (1995). Money and output in modern Greece, 1858-1938. Athens, Centre of Planning and Economic Research: 481.

Maddala, G. S. (1983). Limited-dependent and qualitative variables in econometrics. Cambridge [Cambridgeshire] ; New York, Cambridge University Press.

Meissner, C. M. and A. M. Taylor (2006). "Losing our Marbles in the New Century? The Great Rebalancing in Historical Perspective." National Bureau of Economic Research Working Paper Series No. 12580.

Milesi-Ferrett, G. M. and A. Razin (1998). "Current Account Reversals and Currency Crises: Empirical Regularities." National Bureau of Economic Research Working Paper Series No. 6620.

Mishkin, F. S. (2003). Financial Policies and the Prevention of Financial Crises in Emerging Market Countries. Economic and financial crises in emerging market economies. NBER conference report. M. S. Feldstein. Chicago, University of Chicago Press: pp 93-130. 
Ranciere, R., A. Tornell and F. Westermann (2006). "Decomposing the Effects of Financial Liberalization: Crises vs. Growth." National Bureau of Economic Research Working Paper Series No. 12806.

Stone, I. (1999). The global export of capital from Great Britain, 1865-1914 : a statistical survey. Basingstoke New York, N.Y., Macmillan Press ; St. Martin's Press. 
Table 1: Sudden Stops by Country and Year

(SS1 indicator)

\begin{tabular}{|l|l|}
\hline Country & Year with a Sudden Stop \\
\hline Argentina & 1891,1899 \\
\hline Australia & 1891 \\
\hline Austria & 1899 \\
\hline Brazil & 1906 \\
\hline Canada & 1891,1908 \\
\hline Chile & $1885,1893,1904$ \\
\hline Finland & 1901 \\
\hline Greece & $1883,1886,1892,1900,1906$ \\
\hline India & 1902,1910 \\
\hline Italy & 1888 \\
\hline Japan & $1891,1899,1901,1908$ \\
\hline New Zealand & 1883,1887 \\
\hline Norway & 1902 \\
\hline Portugal & 1892 \\
\hline Russia & $1885,1888,1899$ \\
\hline Sweden & 1886,1911 \\
\hline United States & 1895 \\
\hline &
\end{tabular}


Table 2: Determinants of Sudden Stops

(SS1 indicator)

\begin{tabular}{|c|c|c|c|c|}
\hline \multicolumn{5}{|c|}{ Dependent Variable : Sudden stop Indicator Ss1 } \\
\hline & (1) & (2) & (3) & (4) \\
\hline Trade Balance to GDP & $\begin{array}{c}-0.424 * * \\
{[0.188]}\end{array}$ & $\begin{array}{c}-0.423 * * \\
{[0.207]}\end{array}$ & $\begin{array}{l}-0.317 \\
{[0.259]}\end{array}$ & --- \\
\hline Trade Openness & $\begin{aligned} &-0.100 * * * \\
& {[0.034] }\end{aligned}$ & $\begin{array}{c}-0.099 * * * \\
{[0.032]}\end{array}$ & $\begin{array}{l}-0.112 * \\
{[0.061]}\end{array}$ & $\begin{array}{l}-0.068 \\
{[0.053]}\end{array}$ \\
\hline Gold coverage ratio & $\begin{array}{c}-0.060 * * * \\
{[0.022]}\end{array}$ & $\begin{array}{c}-0.061 * * \\
{[0.024]}\end{array}$ & $\begin{array}{l}-0.021 \\
{[0.035]}\end{array}$ & $\begin{array}{l}-0.018 \\
{[0.030]}\end{array}$ \\
\hline $\begin{array}{l}\text { Original Sin } \\
\text { (Hard Currency Debt to } \\
\text { Total Debt) }\end{array}$ & $\begin{array}{c}0.061 * * * \\
{[0.020]}\end{array}$ & $\begin{array}{c}0.078 * * * \\
{[0.022]}\end{array}$ & $\begin{array}{l}0.053 * * \\
{[0.021]}\end{array}$ & $\begin{array}{l}0.052 * * \\
{[0.021]}\end{array}$ \\
\hline $\begin{array}{l}\text { Hard Currency Debt to } \\
\text { GDP }\end{array}$ & $\begin{array}{l}0.023 \\
{[0.025]}\end{array}$ & --- & --- & --- \\
\hline Total debt to GDP & --- & $\begin{array}{c}0.017 \\
{[0.019]}\end{array}$ & --- & --- \\
\hline $\begin{array}{l}\text { Real GDP per capita } \\
\text { (logs) }\end{array}$ & $\begin{array}{l}-0.008 \\
{[0.013]}\end{array}$ & $\begin{array}{l}-0.008 \\
{[0.014]}\end{array}$ & --- & --- \\
\hline Growth of money $(\%)$ & $\begin{array}{l}-0.022 \\
{[0.068]}\end{array}$ & $\begin{array}{l}-0.031 \\
{[0.070]}\end{array}$ & --- & --- \\
\hline UK Consol Rate & $\begin{array}{l}-0.004 \\
{[0.031]}\end{array}$ & $\begin{array}{l}-0.005 \\
{[0.030]}\end{array}$ & $\begin{array}{l}-0.022 \\
{[0.020]}\end{array}$ & $\begin{array}{l}-0.017 \\
{[0.020]}\end{array}$ \\
\hline Observations & 413 & 414 & 468 & 468 \\
\hline Pseudo R-squared & 0.125 & 0.124 & 0.0493 & 0.0356 \\
\hline $\begin{array}{l}\text { Notes: Dependent variab } \\
\text { Average marginal effect } \\
\text { reported. All regressio } \\
\text { time-effects and a cons } \\
\text { Robust clustered standa } \\
\text { ** significant at } 5 \% ;\end{array}$ & $\begin{array}{l}\text { is a bina } \\
\text { on the pro } \\
\text { include t } \\
\text { ant, not sh } \\
\text { errors in } \\
\text { significa }\end{array}$ & $\begin{array}{l}\text { y indicato } \\
\text { ability of } \\
\text { e UK Conso } \\
\text { wn. } \\
\text { brackets. } \\
\text { t at } 1 \%\end{array}$ & $\begin{array}{l}\text { for sudd } \\
\text { udden st } \\
\text { Rate to } \\
\text { significe }\end{array}$ & $\begin{array}{l}\text { stops. } \\
\text { are } \\
\text { trol for } \\
\text { at } 10 \% \text {; }\end{array}$ \\
\hline
\end{tabular}


Table 3: Marginal Effects on the Probability of a Sudden Stop (based on Model 1 in Table 2)

\begin{tabular}{|l|c|c|c|}
\hline & $\begin{array}{c}\text { Marginal } \\
\text { Effect } \\
{[\mathrm{dp} / \mathrm{dx}]}\end{array}$ & $\begin{array}{c}\text { Standard } \\
\text { Deviation in } \\
\text { variable } \\
{[\mathbf{s d}(\mathbf{x})]}\end{array}$ & $\begin{array}{c}\text { Total Effect } \\
\text { of one s.d. } \\
\text { increase } \\
{[\mathrm{dp} / \mathrm{dx} \text { sd }(\mathbf{x})]}\end{array}$ \\
\hline Trade Balance to GDP & -0.424 & 0.047 & -0.020 \\
\hline Trade Openness & -0.100 & 0.179 & -0.018 \\
\hline gold Coverage ratio & -0.060 & 0.311 & -0.019 \\
\hline Original Sin & 0.061 & 0.337 & 0.020 \\
\hline
\end{tabular}


Table 4: Determinants of Sudden Stops for various

SS identification measures

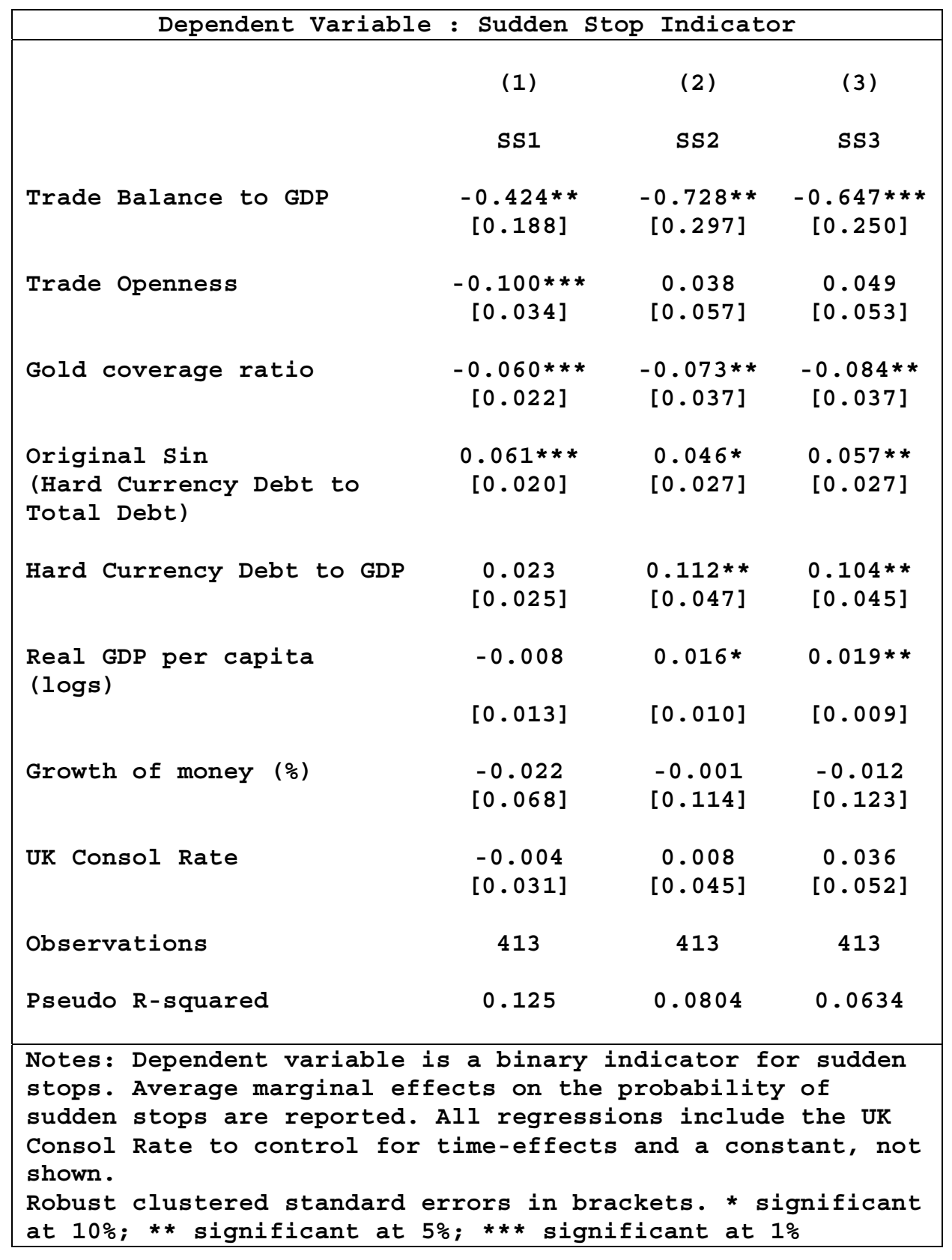


Table 5: Effects of Sudden Stops and Financial Crises on Growth Estimation Using Treatment Effects Model - Maximum Likelihood

\begin{tabular}{|c|c|c|c|}
\hline & (A) & (B) & (C) \\
\hline $\begin{array}{l}\text { Growth Equation } \\
\text { (Dependent Variable is } \\
\text { growth of RGDP per } \\
\text { capita) }\end{array}$ & & & \\
\hline Initial RGDP per capita & $\begin{array}{l}-0.005 \\
{[0.034]}\end{array}$ & $\begin{array}{l}-0.005 \\
{[0.032]}\end{array}$ & $\begin{array}{l}-0.005 \\
{[0.031]}\end{array}$ \\
\hline Inflation & $\begin{array}{c}-0.181 * * * \\
{[0.048]}\end{array}$ & $\begin{array}{c}-0.175 * * * \\
{[0.049]}\end{array}$ & $\begin{array}{c}-0.167 * * * \\
{[0.046]}\end{array}$ \\
\hline Gov. Spending/GDP & $\begin{array}{l}0.000 \\
{[0.003]}\end{array}$ & $\begin{array}{l}-0.000 \\
{[0.003]}\end{array}$ & $\begin{array}{l}-0.000 \\
{[0.003]}\end{array}$ \\
\hline Education Enrollment & $\begin{array}{c}0.190 \\
{[0.242]}\end{array}$ & $\begin{array}{c}0.169 \\
{[0.247]}\end{array}$ & $\begin{array}{c}0.112 \\
{[0.267]}\end{array}$ \\
\hline Investment/GDP & $\begin{array}{l}0.247 * * \\
{[0.115]}\end{array}$ & $\begin{array}{l}0.257 * * \\
{[0.113]}\end{array}$ & $\begin{array}{l}0.247 * * \\
{[0.116]}\end{array}$ \\
\hline Trade Openness (M+X/GDP) & $\begin{array}{l}0.090 * \\
{[0.047]}\end{array}$ & $\begin{array}{l}0.086 * \\
{[0.048]}\end{array}$ & $\begin{array}{l}0.088 * \\
{[0.053]}\end{array}$ \\
\hline Population Growth & $\begin{array}{c}-0.979 * * \\
{[0.398]}\end{array}$ & $\begin{array}{c}-1.004 * * * \\
{[0.375]}\end{array}$ & $\begin{array}{c}-0.955 * * \\
{[0.393]}\end{array}$ \\
\hline Sudden Stop & $\begin{array}{l}-0.041 * * \\
{[0.019]}\end{array}$ & $\begin{array}{c}-0.043 * * \\
{[0.021]}\end{array}$ & $\begin{array}{l}-0.042 * \\
{[0.023]}\end{array}$ \\
\hline Financial Crisis & --- & $\begin{array}{l}-0.018 \\
{[0.012]}\end{array}$ & --- \\
\hline $\begin{array}{l}\text { Financial Crisis with sS } \\
\text { in } t-1 \text { to } t-3\end{array}$ & --- & --- & $\begin{array}{c}-0.036 * * \\
{[0.014]}\end{array}$ \\
\hline $\begin{array}{l}\text { Country Fixed Effects } \\
\text { Constant }\end{array}$ & $\begin{array}{l}\text { Yes } \\
-0.001 \\
{[0.259]}\end{array}$ & $\begin{array}{l}\text { Yes } \\
-0.001 \\
{[0.246]}\end{array}$ & $\begin{array}{l}\text { Yes } \\
0.009 \\
{[0.241]}\end{array}$ \\
\hline \multicolumn{4}{|l|}{$\begin{array}{l}\text { Treatment Probit } \\
\text { (SS1 is Dep. Var.) }\end{array}$} \\
\hline TB to GDP & $\begin{array}{c}-15.636 * * * \\
{[3.046]}\end{array}$ & $\begin{array}{c}-15.590 * * * \\
{[3.037]}\end{array}$ & $\begin{array}{l}-15.541 * * * \\
{[2.990]}\end{array}$ \\
\hline Trade Openness & $\begin{aligned} &-3.679 * * * \\
& {[0.838] }\end{aligned}$ & $\begin{array}{l}-3.662 * * * \\
{[0.818]}\end{array}$ & $\begin{array}{l}-3.673 * * * \\
{[0.810]}\end{array}$ \\
\hline $\begin{array}{l}\text { Original Sin } \\
\text { (Hard Currency Debt } \\
\text { /Total Debt) }\end{array}$ & $\begin{array}{c}0.488 \\
{[0.343]}\end{array}$ & $\begin{array}{c}0.508 \\
{[0.347]}\end{array}$ & $\begin{array}{c}0.512 \\
{[0.348]}\end{array}$ \\
\hline Gold Coverage Ratio & $\begin{array}{l}-0.142 \\
{[0.396]}\end{array}$ & $\begin{array}{l}-0.153 \\
{[0.389]}\end{array}$ & $\begin{array}{l}-0.137 \\
{[0.373]}\end{array}$ \\
\hline Observations & 270 & 270 & 270 \\
\hline $\begin{array}{l}\text { Notes: Top panel is Growt } \\
\text { rate as the dependent val } \\
\text { (probit), with sudden stc } \\
\text { coefficients shown). Robus } \\
\text { * significant at } 10 \% ; * \text { * }\end{array}$ & $\begin{array}{l}\text { egression, } \\
\text { le. Bottom } \\
\text { ummy as the } \\
\text { lustered st } \\
\text { nificant at }\end{array}$ & $\begin{array}{l}\text { real GDP } p \\
\text { is a Treat } \\
\text { ndent vari } \\
\text { d errors ir } \\
\text { ** signif }\end{array}$ & $\begin{array}{l}\text { ita growth } \\
\text { regression } \\
\text { Probit } \\
\text { kets. } \\
\text { at } 1 \%\end{array}$ \\
\hline
\end{tabular}


Figure 1: Sudden Stops and the average Ratio

of Net Capital Inflows to GDP/ by year, 1880-1913

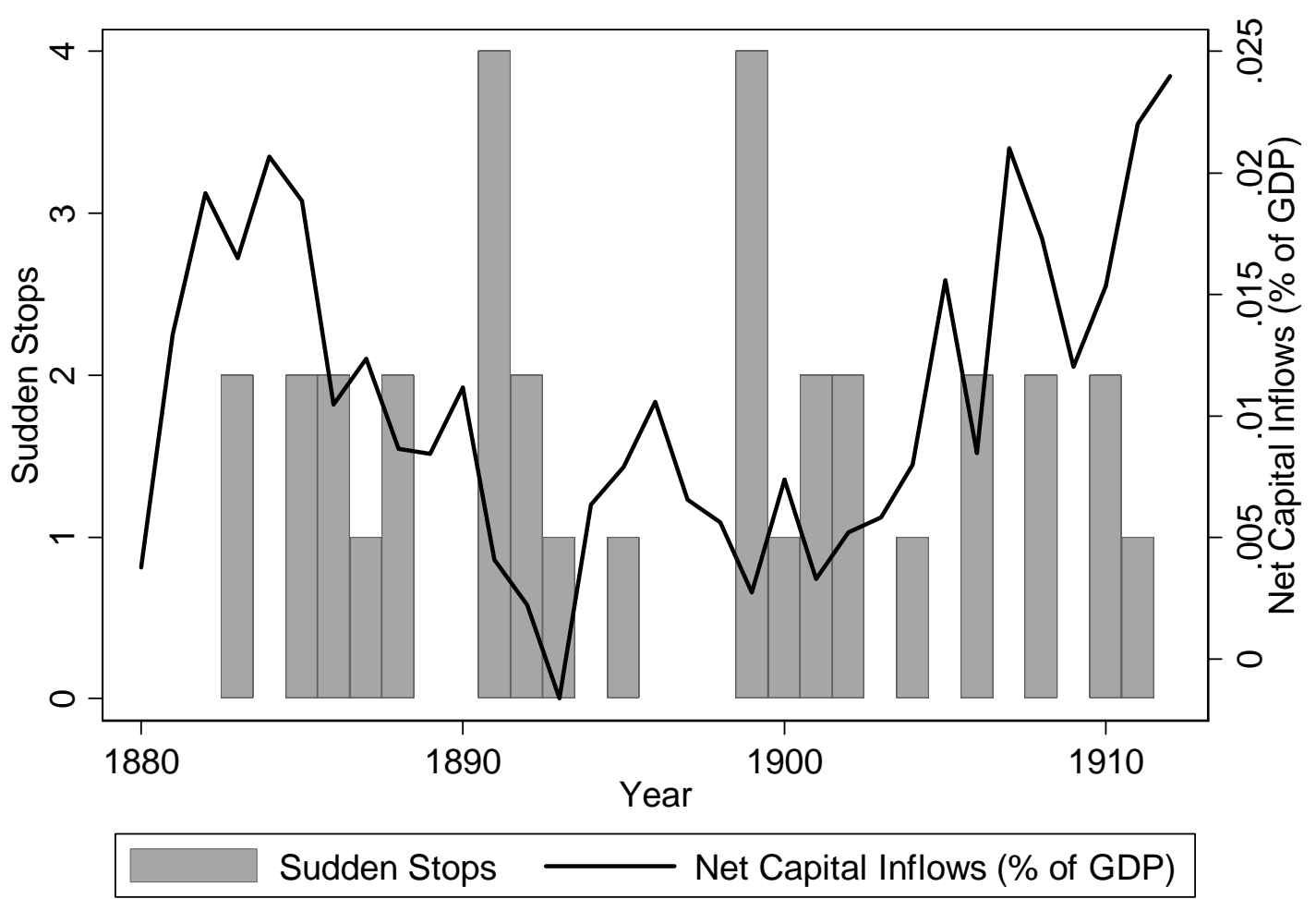

Note: Bars show number of sudden stops in each year 
Figure 2: Frequency of Different Types of Crises 1880-1913

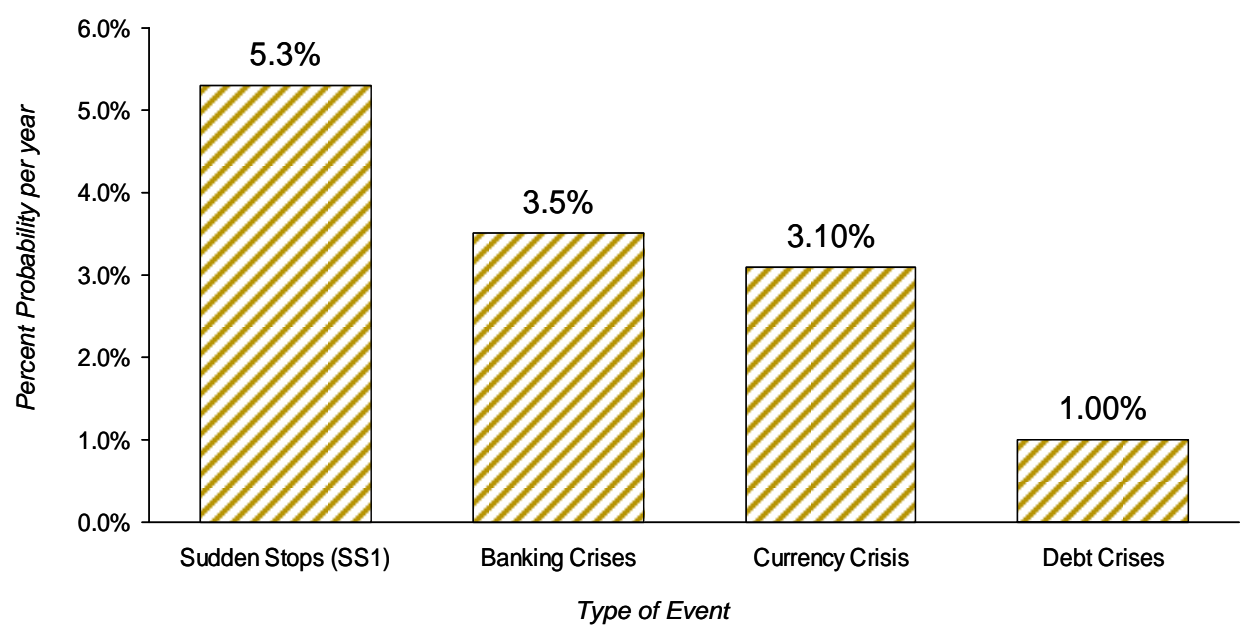

Note: Probability per year $=$ number of years in crisis divided by total possible years of observation (both numerator and denominator exclude years of ongoing crisis

Sources: Other crises dates taken from Eichengreen and Adalet (2005) and Bordo and Meissner (2005)

Figure 3: Discount rates for Core Countries (Lenders) 1880-1913

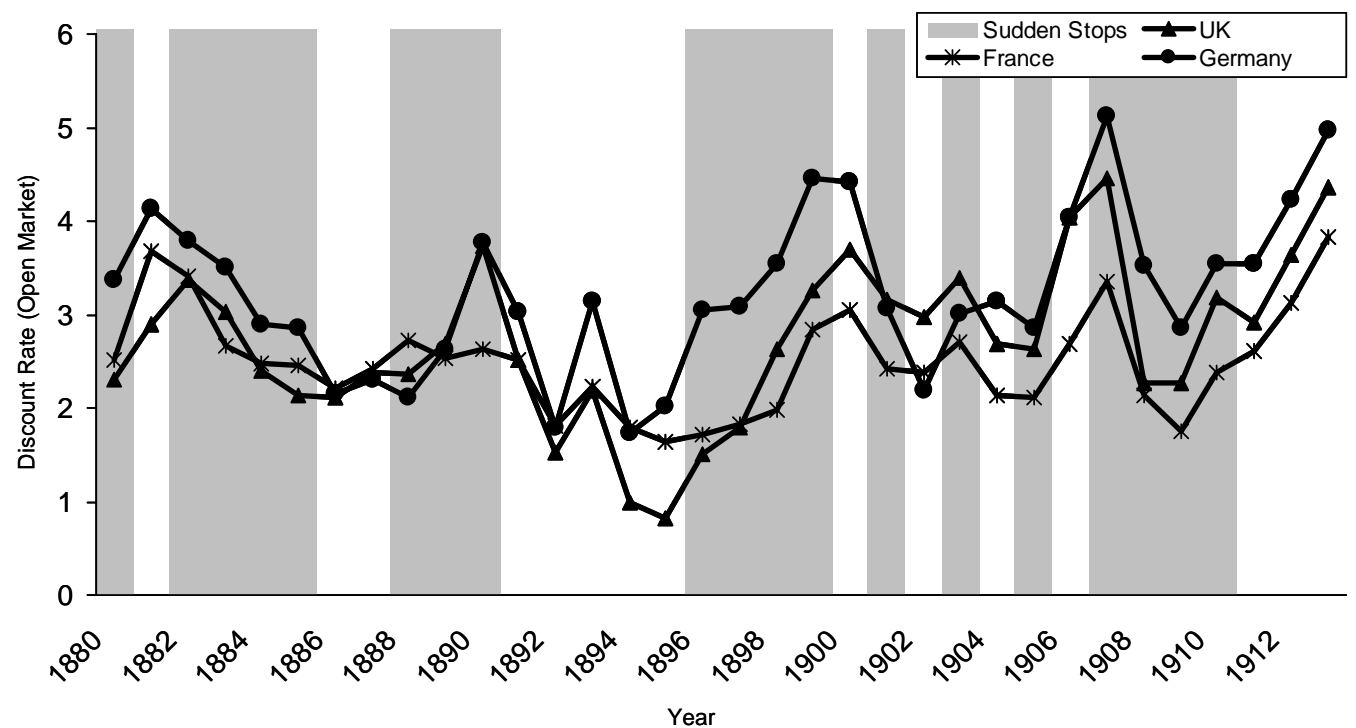

Shaded are years in which a Sudden Stop started for at least one of the countries in the sample Source: Homer and Sylla (2005) for discount rates 


\section{Appendix}

Our dataset is an unbalanced panel with annual data from 1880 to 1913 for 20 emerging market countries: Argentina, Australia, Austria, Belgium, Brazil, Canada, Chile, Denmark, Finland, Greece, India, Italy, Japan, New Zealand, Norway, Portugal, Russia, Spain, Sweden and the United States.

\section{Data sources:}

Bordo et al (2001), Bordo and Meissner (2006), Flandreau and Zúmer (2004), Kostelenos (1995), Mitchell (1992) and Obstfeld and Taylor (2003).

\section{Table A1: Sudden Stop Indicator Variables}

\begin{tabular}{|l|l|l|l|}
\hline Identification Criteria & SS1 & SS2 & SS3 \\
\hline $\begin{array}{l}\text { There is an annual drop in net capital inflows of at least 2 } \\
\text { standard deviations below the mean of the year-to-year changes } \\
\text { for the period in that country }\end{array}$ & $\bullet$ & $\bullet$ \\
$\begin{array}{l}\text { and/or it is the first year of a drop in net capital inflows that } \\
\text { extends over a period shorter than four years and exceeds } 3 \\
\text { percent of that year's nominal GDP }\end{array}$ & $\bullet$ \\
\hline $\begin{array}{l}\text { and there is a drop in real GDP (any magnitude) during that } \\
\text { year or the year immediately after. }\end{array}$ & $\bullet$ & & \\
\hline $\begin{array}{l}\text { and there is a drop in real GDP growth rate during that year or } \\
\text { the year immediately after. }\end{array}$ & & & \\
\hline Number of sudden stops in sample & & & \\
\hline
\end{tabular}


Table A2: All Sudden Stops by Definition, Country and Year

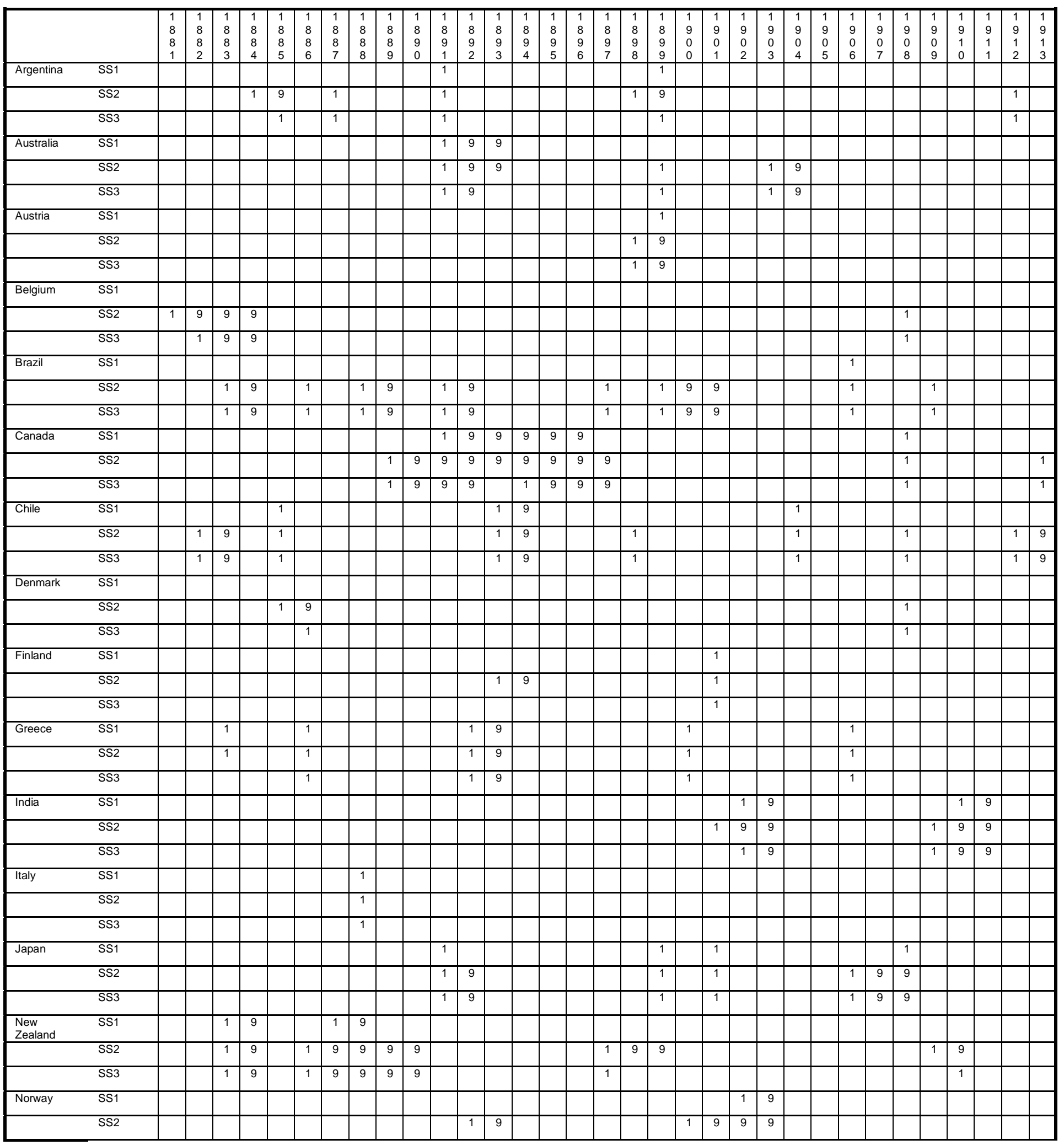




\begin{tabular}{|c|c|c|c|c|c|c|c|c|c|c|c|c|c|c|c|c|c|c|c|c|c|c|c|c|c|c|c|c|c|c|c|c|c|c|}
\hline & & $\begin{array}{l}1 \\
8 \\
8 \\
1 \\
\end{array}$ & $\begin{array}{l}1 \\
8 \\
8 \\
2 \\
\end{array}$ & $\begin{array}{l}1 \\
8 \\
8 \\
3 \\
\end{array}$ & $\begin{array}{l}1 \\
8 \\
8 \\
4 \\
\end{array}$ & $\begin{array}{l}1 \\
8 \\
8 \\
5 \\
\end{array}$ & $\begin{array}{l}1 \\
8 \\
8 \\
6 \\
\end{array}$ & $\begin{array}{l}1 \\
8 \\
8 \\
7 \\
\end{array}$ & $\begin{array}{l}1 \\
8 \\
8 \\
8 \\
\end{array}$ & $\begin{array}{l}1 \\
8 \\
8 \\
9 \\
\end{array}$ & $\begin{array}{l}1 \\
8 \\
9 \\
0 \\
\end{array}$ & \begin{tabular}{|l|}
1 \\
8 \\
9 \\
1 \\
\end{tabular} & $\begin{array}{l}1 \\
8 \\
9 \\
2 \\
\end{array}$ & \begin{tabular}{|l|}
1 \\
8 \\
9 \\
3 \\
\end{tabular} & $\begin{array}{l}1 \\
8 \\
9 \\
4 \\
\end{array}$ & $\begin{array}{l}1 \\
8 \\
9 \\
5 \\
\end{array}$ & $\begin{array}{l}1 \\
8 \\
9 \\
6 \\
\end{array}$ & $\begin{array}{l}1 \\
8 \\
9 \\
7 \\
\end{array}$ & \begin{tabular}{|l|}
1 \\
8 \\
9 \\
8 \\
\end{tabular} & $\begin{array}{l}1 \\
8 \\
9 \\
9 \\
\end{array}$ & $\begin{array}{l}1 \\
9 \\
0 \\
0 \\
\end{array}$ & \begin{tabular}{l|}
1 \\
9 \\
0 \\
1 \\
\end{tabular} & \begin{tabular}{l|}
1 \\
9 \\
0 \\
2 \\
\end{tabular} & $\begin{array}{l}1 \\
9 \\
0 \\
3 \\
\end{array}$ & $\begin{array}{l}1 \\
9 \\
0 \\
4 \\
\end{array}$ & $\begin{array}{l}1 \\
9 \\
0 \\
5 \\
\end{array}$ & \begin{tabular}{|l|}
1 \\
9 \\
0 \\
6 \\
\end{tabular} & \begin{tabular}{l|}
1 \\
9 \\
0 \\
7 \\
\end{tabular} & \begin{tabular}{l|}
1 \\
9 \\
0 \\
8 \\
\end{tabular} & $\begin{array}{l}1 \\
9 \\
0 \\
9 \\
\end{array}$ & $\begin{array}{l}1 \\
9 \\
1 \\
0 \\
\end{array}$ & $\begin{array}{l}1 \\
9 \\
1 \\
1 \\
\end{array}$ & $\begin{array}{l}1 \\
9 \\
1 \\
2 \\
\end{array}$ & $\begin{array}{l}1 \\
9 \\
1 \\
3 \\
\end{array}$ \\
\hline & SS3 & & & & & & & & & & & & & 1 & & & & & & & 1 & 9 & 9 & 9 & & & & & & & & & & \\
\hline Portugal & SS1 & & & & & & & & & & & & 1 & & & & & & & & & & & & & & & & & & & & & \\
\hline & SS2 & & 1 & 9 & & & & & & & & 1 & 9 & & & & & & & & & & & & & & & & & & & & & \\
\hline & SS3 & & 1 & & & & & & & & & 1 & 9 & & & & & & & & & & & & & & & & & & & & & \\
\hline Russia & SS1 & & & & & 1 & 9 & & 1 & 9 & 9 & & & & & & & & & 1 & & & & & & & & & & & 1 & & & \\
\hline & SS2 & & & & & 1 & 9 & 9 & 9 & 9 & 9 & & & & & & & & 1 & 9 & & & & & & & & & & 1 & 9 & & & \\
\hline & SS3 & & & & & & & 1 & 9 & 9 & 9 & & & & & & & & 1 & 9 & & & & & & & & & & 1 & 9 & & & \\
\hline Spain & SS1 & & & & & & & & & & & & & & & & & & & & & & & & & & & & & & & & & \\
\hline & SS2 & & & & & & & 1 & 9 & & & & & & & 1 & 9 & 9 & 9 & & & & & & & & & & & & & & & \\
\hline & SS3 & & & & & & & 1 & 9 & & & & & & & 1 & 9 & 9 & 9 & & & & & & & & & & & & & & & \\
\hline Sweden & SS1 & & & & & & 1 & & & & & & & & & & & & & & & & & & & & & & & & & 1 & 9 & \\
\hline & SS2 & & & & & & 1 & 9 & & & 1 & 9 & 9 & 9 & & & & & & & & & & & & & & & & & & 1 & 9 & 9 \\
\hline & SS3 & & & & & & 1 & & & & 1 & 9 & 9 & 9 & & & & & & & & & & & & & & & & & & 1 & 9 & \\
\hline $\begin{array}{l}\text { United } \\
\text { States }\end{array}$ & SS1 & & & & & & & & & & & & & & & 1 & 9 & & & & & & & & & & & & & & & & & \\
\hline & SS2 & & & & & & & & & & & & & & & 1 & 9 & 9 & & & & & & & & & & & & & 1 & 9 & 9 & \\
\hline & SS3 & & & & & & & & & & & & & & & 1 & 9 & 9 & & & & & & & & & & & & & 1 & & 1 & \\
\hline
\end{tabular}

TableA3: Timing of Sudden Stops vs Financial Crises (SS1 indicator)

\begin{tabular}{|c|c|c|}
\hline & $\begin{array}{c}\text { \# of sudden stops coinciding with a } \\
\text { financial crisis }\end{array}$ & $\%$ of total \\
\hline Same year $(\mathrm{t})$ & 6 & $18 \%$ \\
\hline From $\mathrm{t}$ to $\mathrm{t}+1$ & 7 & $21 \%$ \\
\hline From $\mathrm{t}$ to $\mathrm{t}+2$ & 11 & $32 \%$ \\
\hline From $\mathrm{t}$ to $\mathrm{t}+3$ & 14 & $41 \%$ \\
\hline
\end{tabular}


Table A4: Effects of Sudden Stops and Financial Crises on Growth

Using SS1 as the dependent variable

\begin{tabular}{|c|c|c|c|}
\hline & $(\mathrm{A})$ & (B) & (C) \\
\hline \multicolumn{4}{|l|}{$\begin{array}{l}\text { Growth Equation } \\
\text { (Dependent variable is } \\
\text { growth of Real GDP per } \\
\text { capita) }\end{array}$} \\
\hline Initial RGDP per capita & $\begin{array}{l}-0.003 \\
{[0.032]}\end{array}$ & $\begin{array}{l}-0.003 \\
{[0.031]}\end{array}$ & $\begin{array}{l}-0.007 \\
{[0.031]}\end{array}$ \\
\hline Inflation & $\begin{aligned} &-0.173 * * * \\
& {[0.046] }\end{aligned}$ & $\begin{aligned} &-0.166 * * * \\
& {[0.047] }\end{aligned}$ & $\begin{array}{c}-0.179 * * * \\
{[0.046]}\end{array}$ \\
\hline Gov. Spending/GDP & $\begin{array}{c}0.000 \\
{[0.003]}\end{array}$ & $\begin{array}{c}0.000 \\
{[0.003]}\end{array}$ & $\begin{array}{l}-0.000 \\
{[0.003]}\end{array}$ \\
\hline Education Enrollment & $\begin{array}{c}0.225 \\
{[0.213]}\end{array}$ & $\begin{array}{l}0.209 \\
{[0.212]}\end{array}$ & $\begin{array}{l}0.208 \\
{[0.198]}\end{array}$ \\
\hline Investment/GDP & $\begin{array}{l}0.236 * \\
{[0.121]}\end{array}$ & $\begin{array}{l}0.244 * * \\
{[0.119]}\end{array}$ & $\begin{array}{l}0.228 * \\
{[0.126]}\end{array}$ \\
\hline Trade Openness $(\mathrm{M}+\mathrm{X} / \mathrm{GDP})$ & $\begin{array}{l}0.085 * \\
{[0.045]}\end{array}$ & $\begin{array}{l}0.080 * \\
{[0.046]}\end{array}$ & $\begin{array}{c}0.078 \\
{[0.050]}\end{array}$ \\
\hline Population Growth & $\begin{array}{l}-1.037 * * \\
{[0.422]}\end{array}$ & $\begin{array}{c}-1.068 * * * \\
{[0.397]}\end{array}$ & $\begin{array}{l}-1.007 * * \\
{[0.436]}\end{array}$ \\
\hline Sudden stop & $\begin{array}{l}-0.030 \\
{[0.023]}\end{array}$ & $\begin{array}{l}-0.033 \\
{[0.025]}\end{array}$ & $\begin{array}{l}-0.028 \\
{[0.026]}\end{array}$ \\
\hline Financial Crisis & --- & $\begin{array}{l}-0.018 \\
{[0.012]}\end{array}$ & --- \\
\hline $\begin{array}{l}\text { Financial Crisis with ss } \\
\text { in } t-1 \text { to } t-3\end{array}$ & --- & --- & $\begin{array}{c}-0.056 * * * \\
{[0.012]}\end{array}$ \\
\hline $\begin{array}{l}\text { Country Fixed Effects } \\
\text { Constant }\end{array}$ & $\begin{array}{l}\text { Yes } \\
-0.017 \\
{[0.245]}\end{array}$ & $\begin{array}{l}\text { Yes } \\
-0.019 \\
{[0.234]}\end{array}$ & $\begin{array}{l}\text { Yes } \\
0.015 \\
{[0.234]}\end{array}$ \\
\hline \multicolumn{4}{|l|}{$\begin{array}{l}\text { Treatment Probit } \\
\text { (SS1 is Dep. Var.) }\end{array}$} \\
\hline TB to GDP & $\begin{array}{c}-25.709 * * * \\
{[9.369]}\end{array}$ & $\begin{array}{c}-26.449 * * * \\
{[9.449]}\end{array}$ & $\begin{array}{c}-27.483 * * * \\
{[9.830]}\end{array}$ \\
\hline Trade Openness & $\begin{array}{c}-7.561 * * \\
{[2.954]}\end{array}$ & $\begin{array}{l}-7.722 * * \\
{[3.020]}\end{array}$ & $\begin{array}{c}-8.030 * * \\
{[3.134]}\end{array}$ \\
\hline $\begin{array}{l}\text { Original Sin } \\
\text { (Hard Currency Debt } \\
\text { /Total Debt) }\end{array}$ & $1.454 * * *$ & $1.463 * * *$ & $1.460 * * *$ \\
\hline gold Coverage Ratio & $\begin{array}{c}{[0.196]} \\
-2.024 * * \\
{[0.814]}\end{array}$ & $\begin{array}{c}{[0.213]} \\
-2.057 * * \\
{[0.807]}\end{array}$ & $\begin{array}{c}{[0.233]} \\
-2.052 * * \\
{[0.815]}\end{array}$ \\
\hline Observations & 270 & 270 & 270 \\
\hline $\begin{array}{l}\text { Notes: Top panel is Grow } \\
\text { rate as the dependent va } \\
\text { (probit), with sudden stc } \\
\text { coefficients shown for tl } \\
\text { Robust clustered standarc } \\
\text { * significant at } 10 \% ; \text { * }\end{array}$ & $\begin{array}{l}\text { egression, } \\
\text { le. Bottom } \\
\text { lummy as the } \\
\text { most impor } \\
\text { rrors in bra } \\
\text { jnificant at }\end{array}$ & $\begin{array}{l}\text { real GDP } p \epsilon \\
\text { is a Treat } \\
\text { endent varia } \\
\text { variables. } \\
\text { *** signif }\end{array}$ & $\begin{array}{l}\text { ita growth } \\
\text { regression } \\
\text { Probit }\end{array}$ \\
\hline
\end{tabular}


Table A5: Determinants of Sudden Stops without lags in independent variables (SS1 indicator)

\begin{tabular}{|c|c|c|c|c|}
\hline \multicolumn{5}{|c|}{ Dependent Variable : Sudden stop Indicator SS1 } \\
\hline & (1) & (2) & (3) & (4) \\
\hline Trade Balance to GDP & $\begin{array}{c}0.030 \\
{[0.109]}\end{array}$ & $\begin{array}{c}0.040 \\
{[0.109]}\end{array}$ & $\begin{array}{c}0.184 \\
{[0.223]}\end{array}$ & --- \\
\hline Trade Openness & $\begin{aligned} &-0.093 * * * \\
& {[0.032] }\end{aligned}$ & $\begin{aligned} &-0.095 * * * \\
& {[0.032] }\end{aligned}$ & $\begin{array}{l}-0.059 \\
{[0.046]}\end{array}$ & $\begin{array}{l}-0.077 \\
{[0.060]}\end{array}$ \\
\hline Gold coverage ratio & $\begin{array}{c}-0.044 * * \\
{[0.019]}\end{array}$ & $\begin{array}{c}-0.042 * * \\
{[0.020]}\end{array}$ & $\begin{array}{l}-0.023 \\
{[0.035]}\end{array}$ & $\begin{array}{l}-0.026 \\
{[0.034]}\end{array}$ \\
\hline $\begin{array}{l}\text { Original Sin } \\
\text { (Hard Currency Debt to } \\
\text { Total Debt) }\end{array}$ & $\begin{array}{c}0.064 * * * \\
{[0.020]}\end{array}$ & $\begin{array}{c}0.079 * * * \\
{[0.020]}\end{array}$ & $\begin{array}{l}0.050 * * \\
{[0.024]}\end{array}$ & $\begin{array}{l}0.052 * * \\
{[0.023]}\end{array}$ \\
\hline $\begin{array}{l}\text { Hard Currency Debt to } \\
\text { GDP }\end{array}$ & $\begin{array}{l}0.020 * \\
{[0.012]}\end{array}$ & --- & --- & --- \\
\hline Total debt to GDP & --- & $\begin{array}{c}0.011 \\
{[0.011]}\end{array}$ & --- & --- \\
\hline $\begin{array}{l}\text { Real GDP per capita } \\
\text { (logs) }\end{array}$ & $\begin{array}{c}-0.018 * * \\
{[0.007]}\end{array}$ & $\begin{array}{c}-0.020 * * \\
{[0.008]}\end{array}$ & --- & --- \\
\hline Growth of money $(\%)$ & $\begin{array}{c}0.008 \\
{[0.102]}\end{array}$ & $\begin{array}{c}0.002 \\
{[0.094]}\end{array}$ & --- & --- \\
\hline UK Consol Rate & $\begin{array}{l}-0.002 \\
{[0.030]}\end{array}$ & $\begin{array}{l}-0.005 \\
{[0.029]}\end{array}$ & $\begin{array}{l}-0.017 \\
{[0.021]}\end{array}$ & $\begin{array}{l}-0.020 \\
{[0.020]}\end{array}$ \\
\hline Observations & 423 & 424 & 472 & 472 \\
\hline Pseudo R-squared & 0.105 & 0.103 & 0.0379 & 0.0336 \\
\hline $\begin{array}{l}\text { Notes: Dependent variab } \\
\text { Average marginal effect } \\
\text { reported. All regressio } \\
\text { time-effects and a cons } \\
\text { Robust clustered standa } \\
\text { ** significant at } 5 \% ;\end{array}$ & $\begin{array}{l}\text { is a bina } \\
\text { on the pro } \\
\text { include t } \\
\text { ent, not sh } \\
\text { errors in } \\
\text { significa }\end{array}$ & $\begin{array}{l}\text { indicato } \\
\text { bility of } \\
\text { UK Conso } \\
\text { in. } \\
\text { rackets. } \\
\text { at } 1 \%\end{array}$ & $\begin{array}{l}\text { for sudd } \\
\text { udden st } \\
\text { Rate to } \\
\text { significe }\end{array}$ & $\begin{array}{l}\text { stops. } \\
\text { are } \\
\text { trol for } \\
\text { at } 10 \% \text {; }\end{array}$ \\
\hline
\end{tabular}


Figure A1: Sudden Stops and NKF by country (SS1 Indicator)
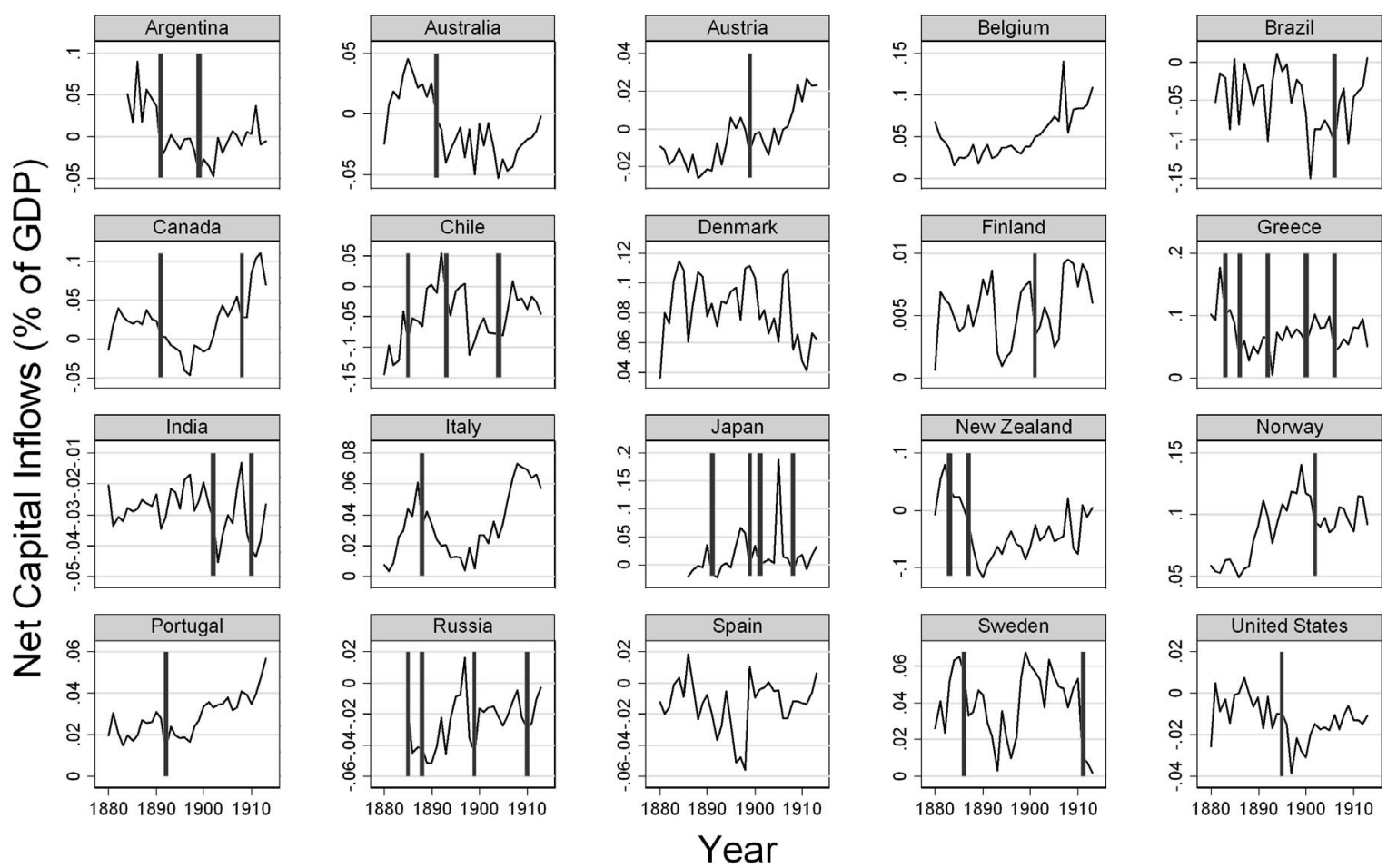

Net Capital Inflows (\% of GDP)

Sudden Stops

Graphs by country 
Figure A2: Sudden Stops and Financial Crises by country

(SS1 indicator)
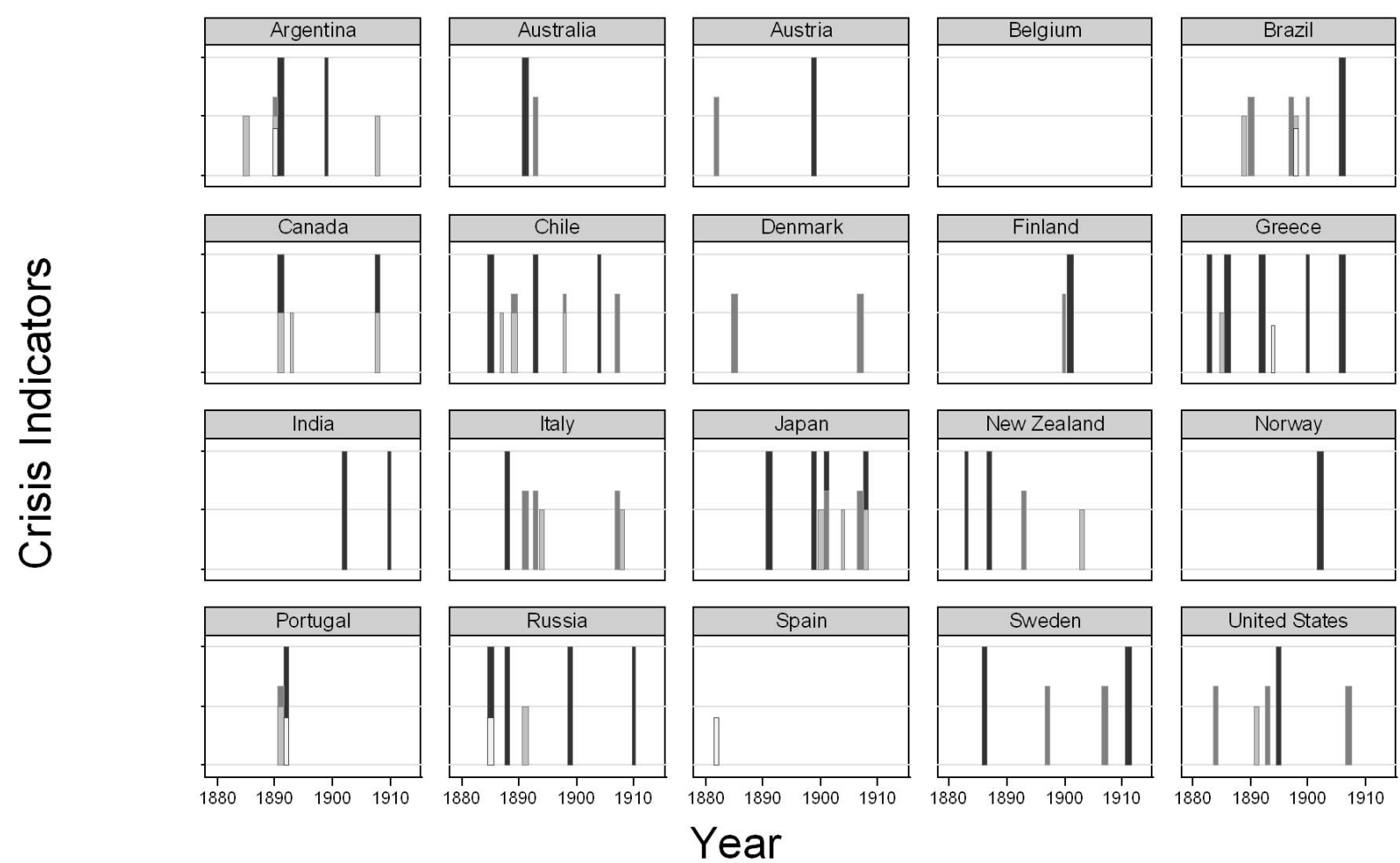

\section{Sudden Stops (highest bar)}

Currency Crisis

\section{Banking Crisis}

Currency Crisis (lowest bar)

Differences in bar height represent different types of crises 